\title{
Tanggung Jawab Pejabat Pembuat Akta Tanah Dalam Memberikan Perlindungan Hukum Bagi Para Pihak Pada Peralihan Hak Atas Tanah Melalui Jual Beli
}

\author{
Purna Noor Aditama \\ purnanooraditama@ymail.com
}

\begin{abstract}
This study aimed to examine the responsibilities and efforts of Land Titles Registrar (PPAT) to provide legal protection for the parties involved in the process of land use right transfer through buying and selling. PPAT as a general official who makes deeds, especially the deed of land use right transfer, must have specific capabilities related to agrarian matters, considering that the deed can be used as proof of evidence that explains the existence of legal acts of right transfer. This research was a normative juridical study that used the qualitative methods while exploring primary legal materials and secondary legal materials to review the legal issue. The results showed that the responsibility and effort of PPAT to provide legal protection for the parties involved in the transfer of buying-selling were carried out from the beginning of the agreement, during the process of buying-selling agreement, and until the transfer of rights was performed in accordance with the regulations about PPAT. The obligations of the seller are protected if the buying-selling object has been fully paid by the buyer, and the rights of the buyer are protected if the process of right transfer up to the inclusion of the name in the certificate and handover of the certificate containing the name of the buyer has been conducted. To be able to provide legal counseling and to give examples of legal consequences if the parties fail to meet the requirements of right transfer, a PPAT has to master and understand all the applicable stipulations relating to the transfer of rights through buying and selling.
\end{abstract}

Keywords: Land Titles Registrar (PPAT); land contracts; land use right transfer

\begin{abstract}
Abstrak
Penelitian ini bertujuan untuk mengetahui tentang tanggung jawab dan upaya-upaya PPAT dalam memberikan perlindungan hukum bagi para pihak dalam proses peralihan Hak Atas Tanah melalui jual beli. PPAT sebagai pejabat umum pembuat akta tertentu khususnya akta peralihan hak tanah, harus memiliki kemampuan khusus di bidang pertanahan, mengingat akta tersebut bisa digunakan sebagai alat bukti yang menerangkan telah terjadi perbuatan hukum pengalihan hak. Jenis penelitian ini bersifat yuridis normatif, dengan menggunakan metode kualitatif, sedangkan untuk mengkaji permasalahan hukum, digunakan bahan hukum primer, dan bahan hukum sekunder. Hasil penelitian menyimpulkan, bentuk tanggung jawab dan upaya-upaya PPAT dalam memberikan perlindungan hukum terhadap para pihak, dalam peralihan hak jual beli, dilakukan sejak awal perjanjian, proses perjanjian jual beli, hingga peralihan hak dilaksanakan sesuai dengan peraturan yang terkait ke PPATan. Kewajiban penjual terlindungi jika obyek jual beli telah dibayar lunas oleh pembeli, dan hak pembeli terlindungi jika proses peralihan hak sampai dengan namanya tercantum dalam sertifikat, dan menerima sertifikat yang sudah atas nama pembeli. Agar bisa memberikan penyuluhan hukum, serta contoh akibat hukum jika para pihak tidak memenuhi persyaratan peralihan hak sesuai dengan apa yang dijelaskan PPAT harus menguasai dan memahami semua ketentuan yang berlaku terkait dengan peralihan hak melalui jual beli.
\end{abstract}

Kata-kata Kunci : PPAT; akta jual beli tanah; peralihan hak atas tanah 


\section{Pendahuluan}

Kedudukan PPAT sebagai pejabat umum dipertegas keberadaannya dalam PP Nomor 24 Tahun 1997 tentang Pendaftaran Tanah. Selanjutnya dalam perkembangan pendaftaran tanah di Indonesia, kedudukan PPAT sebagai pejabat umum dikukuhkan dalam Pasal 1 butir 1 PP Nomor 37 Tahun 1998 tentang Peraturan Jabatan Pejabat Pembuat Akta Tanah. Sebagai pejabat umum PPAT berwenang membuat akta-akta mengenai tanah, harus memiliki kemampuan dan kecakapan khusus di bidang pertanahan agar akta yang dibuatnya tidak menimbulkan masalah dikemudian hari, mengingat akta yang dibuatnya adalah akta otentik yang dapat digunakan sebagai alat bukti, dan mempunyai kekuatan mutlak mengenai hal-hal atau peristiwa yang disebut dalam akta. Oleh karena itu, akta PPAT wajib dibuat sesuai dengan peraturan ke-PPAT-an, sehingga dapat dijadikan dasar kuat untuk pendaftaran pemindahan hak dan pembebanan hak yang bersangkutan, agar dikemudian hari tidak timbul gugatan atau tuntutan terhadap para pihak yang merasa dirugikan.

Macam bentuk perbuatan hukum yang dapat dilakukan oleh PPAT mengenai hak atas tanah, yaitu1: Jual beli; 2) Tukar menukar; 3) Hibah; 4) Pemasukan ke dalam perusahaan; 5) Pembagian hak bersama; 6) Pemberian HGB/HP atas tanah hak milik; 7) Pemberian hak tanggungan; 7) Pemberian kuasa membebankan hak tanggungan.

\section{Rumusan Masalah}

Adapun rumusan masalah yang akan dikaji dalam penelitian ini adalah sebagi berikut: pertama, bagaimanakah bentuk tanggung jawab PPAT dalam memberikan perlindungan hukum bagi para pihak pada peralihan hak atas tanah melalui jual beli? Kedua, bagaimanakah bentuk upaya-upaya PPAT dalam memberikan perlindungan hukum bagi para pihak pada peralihan hak tanah melalui jual beli ?

\section{Tujuan Penelitian}

Tujuan dari penelitian ini adalah: pertama, mengetahui, mengkaji, menganalisis tanggung jawab PPAT dalam memberikan perlindungan hukum bagi

${ }^{1}$ Salim H.S, Teknik Pembuatan Akta Pejabat Pembuat Akta Tanah (PPAT), Cet. 2, Raja Grafindo Persada, Jakarta, 2016, hlm. 74. 
para pihak pada peralihan hak atas tanah melalui jual beli. Kedua, mengetahui upaya-upaya yang dilakukan oleh PPAT dalam memberikan perlindungan hukum bagi para pihak pada peralihan hak atas tanah melalui jual beli.

\section{Metode Penelitian}

Metode penelitian yang digunakan dalam penelitian ini, yaitu yuridis normatif. Dengan menggunakan metode kualitatif. Sebagai obyek penelitian dalam hal ini, yaitu "Tanggung Jawab Pejabat Pembuat Akta Tanah Dalam Memberikan Perlindungan Hukum Bagi Para Pihak Pada Peralihan Hak Atas Tanah Melalui Jual Beli". Sedang sebagai subyek penelitian adalah orang atau pihak-pihak yang akan memberikan data atau informasi yang terkait dengan obyek penelitian diantaranya Notaris-PPAT.

\section{Hasil Penelitian dan Pembahasan}

Tanggung Jawab PPAT dalam Memberikan Perlindungan Hukum Bagi Para Pihak Pada Peralihan Hak Atas Tanah Melalui Jual Beli.

Tanggungjawab Pejabat Pembuat Akta Tanah (PPAT) dalam memberikan perlindungan hukum kepada para pihak, timbul karena adanya perbuatan yang melanggar hukum yang dilakukan PPAT dalam melaksanakan tugas jabatannya, sehingga menyebabkan kerugian bagi para pihak yang meminta jasa pelayanannya. Bentuk tanggungjawab PPAT apabila dikaitkan dengan profesinya menganut prinsip tanggungjawab kesalahan (based on fault of liability). Sehingga dalam pembuatan akta otentik, PPAT harus bertanggungjawab apabila terjadi kesalahan atau pelanggaran terhadap akta yang dibuatnya. Akan tetapi apabila unsur kesalahan atau pelanggaran terjadi dari para pihak, maka PPAT yang bersangkutan tidak dapat diminta pertanggung jawabannya, karena PPAT hanya mencatat apa yang disampaikan oleh para pihak atau penghadap untuk dituangkan ke dalam akta. Keterangan palsu yang disampaikan oleh para pihak adalah menjadi tanggung jawab para pihak2. PPAT dalam hal ini hanya

2 Andi Mamminanga, Pelaksanaan Kewenangan Majelis Pengawas Notaris Daerah dalam Pelaksanaan Tugas Jabatan Notaris berdasarkan UUJN, Tesis, Fakultas Hukum Universitas Gajah Mada, Yogyakarta, 2008, hlm. 32. 
mengkonstatir apa yang terjadi, apa yang dilihat, dan dikatakan oleh para pihak kemudian PPAT menuangkannya ke dalam akta. Sehingga jika terjadi kesalahan yang dilakukan PPAT baik yang disengaja atau karena kelalaiannya menyalahgunakan wewenang PP 37 Tahun 1998 sehingga mengakibatkan orang mengalami kerugian, dan jika kesalahan tersebut dapat dibuktikan oleh pihak yang merasa dirugikan, maka PPAT dapat dikenakan sanksi sesuai perturan Perundang-Undangan.

Untuk itu Pejabat Pembuat Akta Tanah juga harus mencermati secara benar proses tahapan-tahapan yang harus dijalankan baik ketentuan formil maupun materiil dalam pembuatan akta jual beli ${ }^{3}$ yang memenuhi diantaranya yaitu:

1) Syarat formil.

a. Pasal 97 ayat (1) PMNA/KA BPN 3/1997 tentang Pendaftaran tanah;

b. Pasal 96 PERKABAN 8/2012 tentang Perubahan Atas PMNA/KA BPN 3/1997 tentang Ketentuan Pelaksanaan PP Nomor 24 Tahun 1997 tentang Pedafataran Tanah;

c. Pasal 98, ayat (2); Pasal 99 ayat (1); Pasal 101 ayat (1) PMNA/KA BPN 3/1997 tentang Ketentuan Pelaksanaan PP Nomor 24 Tahun 1997 tentang Pendaftaran Tanah;

d. Pasal 23 ayat (1) PP Nomor 37 Tahun 1998 tentang PJPPAT;

e. Pasal 40 ayat (1), (2), PP Nomor 24 Tahun 1997 tentang Pendaftaran Tanah;

f. Pasal 91 ayat (1) UU Nomor 28 Tahun 2009 tentang Pajak Daerah dan Retribusi Daerah.

2) Syarat Materiil. 4

a. Apakah penjual berhak menjual hak atas tanah tersebut;

b. Apakah Pembeli berhak membeli tanah yang bersangkutan. ${ }^{5}$

c. Apakah penjual atau pembeli bertidak sendiri atau sebagai kuasa.

d. Apakah tanah boleh diperjualbelikan dan tidak dalam sengketa.

Dalam hal ini PPAT dalam pembuatan akta otentik, tidak hanya sebatas mengacu pada kebenaran formil yang disampaikan oleh para pihak, karena kebenaran formil belum tentu diikuti oleh kebenaran materiil, sehingga hal ini tentunya akan merugikan pihak penjual, sebagai contoh kasus diatas terlihat pada Keputusan Pengadilan Negeri Sleman No.83/Pdt.G/2013/PN.Slmn. ${ }^{6}$

\footnotetext{
${ }^{3}$ Wawancara, Y.S, Notaris-PPAT, Sleman Yogyakarta, Tanggal 23, Februari, 2017.

${ }^{4}$ Wawancara, Y S, S.H., Notaris-PPAT, Sleman Yogyakarta, Tanggal 23, Februari, 2017.

${ }^{5}$ Urip Santoso., Pendaftaran dan Peralihan Hak atas Tanah, Cetakan ke.3, Kencana Prenada Media Group, Jakarta, 2013, hlm. 368.

${ }^{6}$ Purwanto, Ida Ayu v Budi Prasetyo; Gunawan Wijaya; Sugiharto, S.H, Mohamad Iwan, dan Bank Mega, “Putusan”Pengadilan Pada Tingkat Pertama Pada Pengadilan Negeri Sleman No. 83/Pdt.G/2013/PN.Slmn.
} 
Selanjutnya sebelum akta jual beli dibuat sesuai dengan ketentuan Pasal 37 PP 24/1997 tentang Pendaftaran Tanah. Para pihak disyaratkan untuk menyerahkan surat-surat baik penjual maupun pembeli, yaitu:7

1) Syarat-syarat formil.

a. Identitas Kartu Tanda Penduduk beserta kartu keluarga (KK) penjual. Apabila pemilik hak atas tanah yang tercantum dalam sertifikat suami istri, maka harus ada surat persetujuan suami/istri yang telah dilegalisasi oleh Notaris. Sedangkan untuk hak atas tanah yang berasal dari warisan, untuk WNI pribumi menyerahkan surat keterangan waris yang ditandatangani oleh seluruh ahli waris yang diketahui oleh lurah dan dikuatkan oleh Camat setempat. Sedang untuk WNI non pribumi harus menyerahkan foto copy surat keterangan waris yang dibuat oleh Notaris atau yang berdasarkan penetapan pengadilan sebagaimana ditentukan oleh Surat Direktorat Jendral Agraria Departemen Dalam Negeri No. Dpt/12/63/12/69, tanggal 20 desember 1969 jo pasal 111-112 Peraturan Menteri Negara Agraria/Kepala Badan Pertanahan Nasional Nomor 3 tahun 1997 tentang ketentuan Pelaksanaan Peraturan Pemerintah Nomor 24 tahun 1997 tentang Pendaftaran Tanah.

b. Surat nikah apabila penjual sudah menikah, dan bila ada perjanjian kawin salinan akta perjanjian kawinnya harus dibawa serta surat cerai jika penjual sudah cerai;

c. Bukti pembayaran PBB tahun terakhir beserta keterangan dari Kantor Pelayanan Pajak bahwa tidak terdapat tunggakan Pajak Bumi dan Bangunan (PBB) atau tanda bukti pembayaran PBB 5 (lima) tahun terakhir;

d. Bukti PBB tahun terakhir akan dipergunakan PPAT untuk menentukan besar Pajak Penghasilan (PPh) atas peralihan hak atas tanah bagi penjual dan untuk menghitung besar pajak Bea Perolehan Hak Atas Tanah dan Bangunan (BPHTB) untuk pembeli;

e. Bukti pelunasan atau pembayaran pajak Penghasilan atas Penghasilan dari Pengalihan Hak Atas Tanah dan / atau Bangunan sesuai dengan PP Nomor 71 Tahun 2008 tentang Perubahan Ketiga Atas Peraturan Pemerintah Nomor 48 Tahun 1994 tentang Pembayaran Pajak Penghasilan atas Penghasilan dari Pengalihan Hak Atas tanah dan/atau Bangunan;

f. Nomor Pokok Wajib Pajak sesuai dengan ketentuan Peraturan Direktur Jenderal Pajak Nomor 35/Pj/2008 tentang Kewajiban Pemilihan Nomor Pokok Wajib Pajak dalam rangka Pengalihan Hak Atas tanah dan Bangunan (BPHTB) dengan menggunakan SSB yang disebabkan adanya

${ }^{7}$ Wawancara, A.K, Notaris-PPAT, Purwokerto, Tanggal 23, Februari, 2017. 
pengalihan hak atas tanah dan/atau bangunan wajib dicantumkan NPWP yang dimiliki Wajib Pajak yang bersangkutan.

2) Sedang syarat formil. ${ }^{8}$

a. Jika hak atas tanah sudah terdaftar, pihak pembeli harus menyerahkan sertifikat asli untuk dilakukan pengecekan kesesuaian data di Kantor Pertanahan. Tindakan ini dilakukan sesuai ketentuan Pasal 97 ayat (1) PMNA/Ka BPN 3/1997 tentang Ketentuan Pelaksanaan PP No. 24 Tahun 1997 Tentang Pendaftaran Tanah.

b. Pembuatan akta jual beli harus dihadiri oleh para pihak atau kuasa yang sah serta disaksikan oleh 2 (dua) orang saksi sesuai dengan ketentuan Pasal 101 ayat (2) PMNA/Ka BPN 3/1997 tentang Ketentuan Pelaksanaan PP No. 24 Tahun 1997 Tentang Pendaftaran Tanah

c. Penandatanganan akta jual beli harus dilakukan sesuai dengan ketentuan Pasal 101 ayat (1) PMNA/Ka BPN 3/1997 tentang Ketentuan Pelaksanaan PP No. 24 Tahun 1997 Tentang Pendaftaran Tanah

d. Pembuatan dan penandatanganan akta jual beli sesuai dengan ketentuan Pasal 101 ayat (2) PMNA/Ka BPN 3/1997 tentang Ketentuan Pelaksanaan PP No. 24 Tahun 1997 Tentang Pendaftaran Tanah;

e. Pembuatan akta harus dilakukan di kantor PPAT sesuai Pasal 12 PJPPAT,

f. PPAT harus membacakan dan menjelaskan isi dari akta jual beli dihadapan para pihak sesuai ketentuan Pasal 101 ayat (3) PMNA/Ka BPN 3/1997 tentang Ketentuan Pelaksanaan PP No. 24 Tahun 1997 Tentang Pendaftaran Tanah.

g. Nilai harga transaksi yang dimuat di akta jual beli harus sesuai dengan Pasal 87 ayat (1) dan ayat (2) huruf a UU No. 28 Tahun 2009 Tentang Pajak Daerah Dan Retribusi Daerah;

h. Penandatanganan akta jual beli harus dilakukan setelah para pihak melakukan pembayaran pajak, yakni Pajak Penghasilan (PPh) dan Pajak Bea Perolehan Hak Atas Tanah dan Bangunan (BPHTB) bagi Pembeli sesuai dengan ketentuan Pasal 91 ayat (1) UU No. 28 Tahun 2009 Tentang Pajak Daerah Dan Retribusi Daerah;

i. Selambat-lambatnya 7 (tujuh) hari kerja setelah akta tersebut dibuat sejak tanggal ditandatanganninya akta yang bersangkutan. PPAT wajib menyampaikan akta yang dibuatnya berikut dokumen-dokumen yang terkai dengan akta tersebut kepada Kantor Pertanahan untuk didaftar dan PPAT wajib menyampaikan pemberitahuan tertulis mengenai telah disampaikannya akta tersebut kepada para pihak yang bersangkutan.

\section{Tanggung Jawab PPAT Secara Administratif}

PPAT sebagai pejabat publik, jika dalam melaksanakan tugas tidak sesuai dengan kewenangannya yakni melanggar Pasal 62 PP No. 24 Tahun 1997 tentang Pendaftaran Tanah, bisa dikenakan tindakan sanksi administratif sampai dengan

\footnotetext{
${ }^{8}$ Wawancara, A.K, Notaris-PPAT, Purwokerto, Tanggal 23, Februari, 2017.
} 
pemberhentian dari jabatannya oleh Kepala Badan Pertanahan Nasional Indonesia. Sanksi administrasi yang dikenakan PPAT akibat melanggar Pasal 11 ayat (1), Pasal 13 ayat (2), dan Pasal 15 ayat (1) Undang-Undang No. 4 Tahun 1996 tentang Hak Tanggungan atas Tanah Beserta benda-Benda yang berkaitan dengan Tanah, dan sesuai dengan Pasal 6 ayat (1) Kode Etik IPPAT, Pasal 23 ayat (1) dapat berupa sanksi, yaitu 1) Teguran; 2) Peringatan; 3) Schorsing dari keanggotaan IPPAT; 4) Pemberhentian dari keanggotaan IPPAT; 5) Pemberhentian dengan tidak hormat dari keanggotaan IPPAT.

Selain tanggung jawab administratif, PPAT juga diberi tanggung jawab terkait dengan perpajakan yang merupakan bentuk kewenangan tambahan PPAT yang diberikan Undang-Undang Perpajakan9 yaitu PP No. 71 Tahun 2008 tentang Perubahan Ketiga Atas Peraturan Pemerintah No 48 Tahun 1994 tentang Pembayaran Pajak Penghasilan Atas Penghasilan dari Pengalihan Hak Atas Tanah dan atau Bangunan (BPHB) dan Undang-Undang Nomor 28 Tahun 2009. Sedang kewenangan untuk menentukan perlu tidaknya BPHTB divalidasi dalam peralihan hak atas tanah, sesuai dengan UU Nomor 28 Tahun 2009, menjadi kewenangan Perda masing-masing daerah, karena BPHTB merupakan pajak daerah.

Menurut pendapat penulis semestinya instansi pemerintah daerah jelas tidak mempunyai kewenangan hak untuk turut serta atau ikut campur atau bahkan menentukan harga bidang tanah tertentu yang menjadi obyek peralihan hak jual beli tersebut, bahkan bisa dikatakan pejabat institusi pemda tersebut dapat dikatakan sebagai telah melakukan penyalahgunaan wewenang. ${ }^{10}$

Wajib pajak semestinya yang memiliki kewajiban untuk menghitung dan membayar pajaknya sendiri, karena sistem perpajakan Indonesia menganut sistem "selft assessment", sehingga wajib pajak yang mempunyai kewajiban untuk menghitung dan membeyar pajaknya masing-masing. Jika ada kekurangannya, maka kantor pajak dapat meminta kekurangan tersebut kepada wajib pajak. Badan Pertanahan Nasional dalam peralihan hak atas tanah tidak perlu melibatkan diri

${ }^{9}$ Wawancara, D H D, Notaris-PPAT, Yogyakarta, Tanggal 15, Februari, 2017.

${ }_{10}$ Mulyoto., Legal Standing, Cakrawala Media, Yogyakarta, 2016, hlm 84-85. 
terlalu dalam mengenai masalah pajak PPh dan BPHTB, karena hal tersebut bukan kewenangan Kantor Pertanahan, akan tetapi sudah menjadi ranah Pemerintah Daerah.

Kantor Pertanahan dalam masalah peralihan hak, lebih baik memfokuskan dalam memberikan pelayananan agar lebih baik dan lancar terhadap masyarakat, dari pada ikut meributkan masalah validasi pajak yang akhirnya malah justru membuat pelayanan dan penyelesaian pendaftaran tanah menjadi terhambat. Kantor Pertanahan dalam hal ini lebih baik berpegang pada Surat Edaran Kepala BPN RI No. 05/SE/IV/2013 yang memerintahkan kepada Kepala kantor Pertanahan untuk menerima pendaftaran peralihan walaupun BPHTBnya belum divalidasi. Masalah pajak menjadi wewenang Pemerintah Daerah sesuai dengan UU No. 28 Tahun 2009, bukan Kantor Pertanahan.

\section{Tanggung Jawab PPAT Secara Perdata}

Pertanggung jawaban PPAT secara perdata terkait dengan kesenjangan, kealpaan dan/atau kelalaiannya dalam pembuatan akta jual beli yang menyimpang dari syarat formal dan materiil. PPAT tidak saja hanya dapat dikenakan sanksi administratif tapi juga dituntut ganti kerugiann secara perdata oleh para pihak yang dirugikan. PPAT dapat dituntut secara perdata apabila para pihak melakukan pengingkaran terhadap apa yang tertulis di dalam akta.

Berpijak pada prinsip umum tersebut, maka penulis berasumsi bahwa perbuatan PPAT yang telah menyebabkan sebuah akta menjadi cacat hukum dapat dianggap sebagai perbuatan melanggar hukum, jika perbuatan yang dilakukan PPAT bertentangan dengan kewajiban hukum para pihak; hak subjektif para pihak; kesusilaan; kepatutan; ketelitian, dan kehati-hatian. Jika PPAT melanggar salah satu kriteria tersebut, maka bisa dikatakan bahwa PPAT sudah cukup syarat melakukan suatu perbuatan melanggar hukum, jadi perbuatan melanggar hukum dalam hal ini tidak harus memenuhi keempat kriteria itu secara kumulatif. ${ }^{11}$

Sanksi perdata dijatuhkan kepada PPAT jika perbuatan yang dilakukan menimbulkan kerugian, dan secara normatif tunduk pada ketentuan Pasal 1365 KUHPerdata. Namun apabila dalam pelaksanaan tugas dan jabatan akta

11 Wawancara, D.H.D, Notaris-PPAT, Jogyakarta, Tanggal 15, Februari, 2017. 
mengandung cacat hukum, yang kemudian oleh suatu putusan pengadilan dinyatakan tidak otentik, karena tidak memenuhi syarat formil dan materiil, sehingga kekuatan akta hanya dibawah tangan, dan akan mengakibatkan kesulitan bagi pihak-pihak atau orang yang berhak atas akta untuk melaksanakan haknya yang dijamin Undang-Undang, yaitu hak untuk mempergunakan akta sebagai alat bukti hak yang sah; mendalilkan haknya, membantah hak orang lain.

\section{Tanggung Jawab PPAT Secara Pidana}

Penjatuhan sanksi pidana dapat dilakukan sepanjang PPAT telah membuat surat palsu atau memalsukan akta dengan kualifikasi sebagai suatu tindak pidana. Syarat materiil dan syarat formil dari prosedur pembuatan akta PPAT merupakan aspek-aspek formal yang harus dilalui dalam pembuatan akta jual beli tanah berkaitan dengan tugas jabatan PPAT. Penjatuhan sanksi pidana dapat dilakukan sepanjang batasan-batasan yang ditentukan Perundang-Undangan terkait PPAT, PJPPAT; Kode etik PPAT, dan rumusan yang tersebut dalam Kitab UndangUndang Hukum Pidana (KUHP) dilanggar.

Sehubungan dengan hal tersebut, penulis berpendapat seorang PPAT tidak bisa diminta pertanggungjawaban pidana atas akta yang dibuatnya apabila PPAT bersangkutan telah melakukan tugasnya sesuai dengan prosedur sebagaimana yang diatur dalam peraturan Perundang-undangan., yang terkait dengan PPAT, PJPPAT, Kode etik PPAT, dan PerkaBPN. Hal ini dilegitimasi dalam Pasal 266 KUHP, dimana seorang PPAT tidak bisa dikenakan pidana atas dasar Pasal 266 KUHP apabila ia telah menjalankan tugasnya dengan benar. ${ }^{12}$

Posisi PPAT dalam hal ini adalah orang yang hanya disuruh (manus ministra) dan dalam kontek pembuatan akta jual beli hanya merupakan media (alat) untuk lahirnya suatu akta otentik, sedangkan inisiatif timbul dari para penghadap/para pihak sehingga dalam hal ini PPAT adalah pihak yang disuruh bukan pihak yang menyuruh. Namun apabila seorang PPAT telah dengan sengaja dan diinsyafi atau disadari bekerja sama dengan penghadap, maka PPAT dapat dikenakan Pasal 263

12. Wawancara, A.K, Notaris-PPAT, Purwokerto, Tanggal 23, Februari, 2017. 
ayat (1) KUHPidana yang dikaitkan dengan Pasal 55 (1), yaitu turut serta melakukan tindak pidana. Selain itu karena produk yang dihasilkan oleh PPAT dikenakan pemberatan yang sebagaimana yang diatur dalam Pasal 264 ayat (1) huruf a KUHP Jo Pasal 55 ayat (1) KUHP.

\section{Upaya-Upaya Pejabat Pembuat Akta Tanah (PPAT) dalam Memberikan Perlindungan Hukum Bagi Para Pihak Pada Peralihan Hak Tanah Melalui Jual Beli}

Bentuk upaya tindakan PPAT dalam memberikan perlindungan hukum terhadap para pihak dalam perjanjian jual beli, dan proses peralihan hak atas tanah, pada prinsipnya, yakni sepanjang hak dan kewajiban penjual dan pembeli dalam jual beli tersebut telah terpenuhi sesuai Pasal 52; Pasal 53, dan Pasal 54 PERKABAN; syarat sah perjanjian jual beli sesuai Pasal 1320 KUHPerdata, serta terpenuhinya tiga (3) ketentuan yang ditentukan hukum adat yaitu tunai, riil, dan terang.

Sedangkan bentuk kewajiban dan hak penjual maupun pembeli yang perlu dilaksanakan oleh masing-masing pihak, dalam melakukan proses jual beli, diantaranya yaitu: ${ }^{13}$

1) Kewajiban Penjual.

a. Penjual menjamin Legal Standing terpenuhi, yaitu

a) Penyerahan (levering) atau memindahkan hak miliknya atas barang secara yuridis, bukan sekedar penyerahan secara feitelijk;

b) Penjual benar merupakan satu-satunya atau keseluruhan pemilik obyek jual beli atau obyek peralihan hak atas tanah;

c) Jika dikemudian hari ada gugatan dan tuntutan dari pihak yang merasa dirugikan, karena mereka merasa berhak, lebih berhak, serta turut berhak, maka penjual sanggup untuk menghadapi atau menyelesaikan atas biaya penjual sampai dengan pembeli terbebas dari hal tersebut menjadi benar-benar aman;

b. Penjual menyerahkan obyek yang diperjualbelikan, dan menjamin kenikmatan atas barang tersebut, menanggung terhadap cacad-cacad yang tersembunyi, dan terhadapnya berhak untuk menerima pembayaran harga barang.

c. Penjual menjamin penguasaan obyek jual beli atau peralihan hak aman, tentran, bebas dari sengketa, dan obyek tidak sedang dijaminkan.

2) Hak penjual.

a. Menerima harga permbayaran atas penjualan obyek jual beli sesuai dengan kesepakatan kedua belah pihak, mengenai kondisi dan nilai tukar barang yang diperdagangkan; 
b. Mendapatkan pelunasan harga obyek jual beli atau peralihan hak atas tanah,

c. Penjual juga berhak mendapatkan perlindungan hukum dari tindakan pembeli yang beritikad tidak baik,

d. Hak untuk melakukan pembelaan diri sepatutnya dalam suatu penyelesaian sengketa dikarenakan barang yang dijualnya;

e. Hak-hak diatur dalam ketentuan peraturan Perundang-undangan.

3) Kewajiban pembeli.

a. Membayar lunas atas harga barang obyek jual beli (peralihan hak) atas bidang tanah sebagaimana yang ditetapkan perjajian,

4) Hak Pembeli.

a. Tidak akan menerima gugatan dan tuntutan berupa apapun dan dari siapapun atau pihak manapun dalam pembelian atas obyek atau peralihan hak atas jual beli tersebut aman, ada kepastian hukum,

b. Menerima penyerahan atas barang (peralihan hak) atau hak atas bidang tanah yang menjadi obyek jual beli dari penjual.

Sedang menurut ketentuan Pasal 1320 BW, untuk memenuhi syarat syahnya sebuah perjanjian jual beli, yakni: 1) adanya kesepakatan para pihak dalam perjanjian; 2) adanya kecakapan para pihak dalam perjanjian; 3) suatu hal tertentu; 4) suatu sebab yang halal. Persyaratan pertama (1) dan ke dua (2) berkenan dengan subjek perjanjian, sedang persyaratan yang ke tiga (3) dan ke empat (4) berkenan dengan objek perjanjian. Sedang menurut hukum adat, perbuatan hukum pengalihan hak atas tanah akibat adanya jual beli mensyaratkan harus memenuhi 3 sifat yaitu tunai; terang, riil atau nyata riil.

Adapun upaya tindakan nyata PPAT dalam memberikan upaya perlindungan hukum terhadap para pihak sebelum pembuatan akta antara lain, yaitu:

a. Para pihak harus memenuhi ketentuan syarat formil tentang tata cara pembuatan akta PPAT yang tersebar dalam berbagai peraturan yang terkait kePPAT-an diantaranya yaitu Pasal 24 PP No. 37 Tahun 1998, Pasal 51-55 PERKABAN No. 1 Tahun 2006 tentang Ketentuan Pelaksanaan PP No. 37 Tahun 1998 tentang PJPPAT, dan peraturan yang berkaitan dengan perpajakan.

b. Para pihak harus memenuhi ketentuan syarat materiil pembuatan akta PPAT. sesuai dengan Pasal 97 ayat (1) PMNA/Ka BPN 3/1997 yang bertujuan, yaitu: 
c. Akta jual beli harus dibacakan oleh PPAT secara rinci dan PPAT harus menerangkan maksud tujuan dari isi akta secara keseluruhan.

d. Penandatanganan terhadap akta jual beli dilakukan oleh para pihak secara bersamaan;

e. Saksi-saksi harus terlibat secara langsung dalam suatu proses penandatanganan akta;

f. Nilai harga transaksi yang dimuat dalam akta jual beli harus sama dengan nilai transaksi yang sebenarnya.

Terkait dengan perlindungan hukum terhadap PPAT sendiri berdasarkan peraturan jabatannya, bentuk perlindungan hukum bagi PPAT dalam ranah peraturan Perundang-undangan terkait ke-PPAT-an lebih bersifat intern atau administratif. Sebagian besar peraturan yang dilanggar oleh PPAT adalah ukuran standar profesionalisme yang seharusnya wajib ditaati oleh semua PPAT dalam pembuatan akta otentik dibidang pertanahan. Sedangkan Badan Pertanahan Nasional (BPN) sebagai Pejabat Tata Usaha Negara, yang terkait dengan keberadaan PPAT sebagai pejabat publik, Badan Pertanahan Nasional berhak dalam memberikan sanksi terhadap PPAT jika melanggar parturan dan Perundang-Undangan, dengan mengeluarkan surat keputusan (KTUN), dan apabila dalam hal ini PPAT tidak puas terhadap keputusan yang dijatuhkan oleh BPN, maka keputusan tersebut akan menjadi sengketa Tata Usaha Negara. Sedang upaya yang dapat dilakukan oleh PPAT dalam hal ini, yaitu langsung mengajukan gugatan ke Pengadilan Tata Usaha Negara sebagai pengadilan atau pemeriksaan tingkat pertama.

Terkait dengan pengawasan terhadap PPAT, perlu mekanisme pengawasan baik yang bersifat preventif maupun represif sesuai Peraturan Jabatan PPAT Pasal 33 PP No. 37 Tahun 1998, yang pelaksanaannya diatur dalam Pasal 65-68 PERKABAN 1/2006 tentang Ketentuan Pelaksanaan PP No. 37 Tahun 1998 tentang PJPPAT; melalui organisasi profesi PPAT yaitu Ikatan Pejabat Pembuat Akta Tanah (IPPAT), dan Pasal 28 ayat (2) huruf c PERKABAN 1/2006 tentang Ketentuan Pelaksanaan PP No. 37 Tahun 1998 tentang PJPPAT, disebutkan bahwa PPAT diberhentikan dengan tidak hormat dari jabatannya oleh Kepala Badan (BPN) karena melanggar kode etik profesi. 
Selain itu, sebagai Pejabat Umum, sudah seharusnya PPAT perlu diberikan perlindungan hukum untuk tetap menjaga keluhuran harkat dan martabat jabatannya, termasuk ketika memberikan kesaksian dan berproses dalam pemeriksaan dan persidangan; merahasiakan akta dan keterangan yang diperoleh guna pembuatan akta; menjaga Minuta Akta PPAT dan warkah pendukung akta yang dilekatkan pada minuta akta atau protokol PPAT dalam penyimpanan PPAT. Walaupun dalam hal ini PJPPAT tidak mengatur secara eksplisit mengenai prosedur khusus dalam penegakan hukum terhadap PPAT, akan tetapi secara prosedur etik, pemanggilan PPAT sebagai saksi tersebut minimal atau tetap harus memberi tahu Ikatan Pejabat Pembuat Akta tanah (IPPAT) sebagai pengawas PPAT, dan/atau apabila pihak kepolisian dalam hal ini penyidik hendak meminta keterangan dari PPAT, akan lebih bijak pihak penyidik yang datang ke kantor. Di sisi lain menjadi kewajiban formal dan terstruktur dari IPPAT untuk melakukan pendampingan kepada PPAT yang dipanggil oleh penyidik, kejaksaan dan hakim. Berkaitan dengan hal tersebut hendaknya perlu adanya Peraturan Kepala BPN RI perihal pemanggilan PPAT penegak hukum (penyidik, kejaksaan, dan hakim maupun penyitaan minuta akta PPAT untuk menghindari kesemenaan dari oknum tertentu.

\section{Penutup}

Berdasarkan kajian di atas, dapat disimpulkan, pertama, bentuk tanggung jawab Pejabat Pembuat Akta Tanah dalam memberikan perlindungan hukum terhadap para pihak yaitu dengan terpenuhinya hak dan kewajiban penjual dan pembeli sejak ditandatanganinya akta jual beli dihadapanya (PPAT), didaftarkannya proses peralihan hak atas tanah, hingga paska diterimanya sertifikat hak atas tanah sesuai yang dikehendaki pembeli, dan dikemudian hari tidak ada gugatan, dan tuntutan dalam bentuk apapun dan dari pihak manapun akibat adanya perubahan kepemilikan hak atas tanah tersebut, sehingga pembeli merasa aman dalam membeli tanah tersebut, begitu juga penjual aman dalam menjual hak atas tanahnya. 
Kedua, upaya-upaya yang dilakukan PPAT dalam memberikan perlindungan hukum bagi para pihak dalam perbuatan hukum jual beli, yaitu terpenuhinya Pasal 1320 KUHPerdata tentang syarat syahnya jual beli, yaitu dengan dipenuhinya legal standingnya; adanya kata sepakat; kecakapan untuk membuat suatu perikatan; hal tertentu, dan suatu hal yang halal; terpenuhinya persyaratan peralihan hak atas tanah, dan melakukan pengecekan terhadap pajak BPHTB serta PPh, dan oleh karena peralihan hak atas tanah di Indonesia mendasarkan pada hukum adat, maka jual beli juga harus memenuhi syarat tunai, terang, dan nyata.

Adapun saran dari penulis kepada PPAT, pertama, agar PPAT dalam melaksanakan tugas tidak hanya mengejar kebenaran formiil akan tetapi harus terpenuhinya kebenaran materiil; mampu memberikan penyuluhan hukum kepada calon penjual dan pembeli, dan bisa memberikan contoh akibat hukum jika para pihak tidak memenuhi persyaratan sesuai dengan yang sebenarnya apa yang dijelaskan oleh PPAT. Kedua, mengingatkan kembali Kepala Kantor Pertanahan, dan Kantor Wilayah Badan Pertanahan Nasional (BPN) perihal Surat Edaran Kepala BPN Republik Indonesia Nomor. 05/SE/IV/2013 agar dilaksanakan, dan ditindaklanjuti mengenai ketidak harusan adanya validasi terlebih dahulu terhadap BPHTB dan PPh dalam proses peralihan hak atas tanah.

Sedangkan saran kepada BPN, pertama, agar surat kepala BPN Republik Indonesia No.05/SE/IV/2013 mengenai tidak adanya keharusan validasi terlebih dahulu terhadap BPHTB dan PPh dilaksanakan; Kedua, agar Kantor Pertanahan dalam melakukan pendaftaran tanah sesuai dengan Sistem Operasional Prosedur (SOP) atau juklak yang sudah digariskan oleh Badan Pertanahan Nasional (BPN), sehingga proses peralihan hak atas tanah bisa berjalan cepat dan efektif; tidak ada kesan mempersulit pemohon, sebagai misal permasalahan nama dalam sertifikat yang tidak sesuai dengan nama yang ada dalam Kartu Tanda Panduduk.(KTP) akibat peraturan EYD.

\section{Daftar Pustaka}

\section{Buku}

AP. Parlindungan, Pendaftaran Tanah Di Indonesia, Cet 2, Mandar Maju, Bandung, 1994. 
Achmad Chulaemi, Hukum Agraria Perkembangan Macam-macam Hak Atas Tanah dan Pemindahannya, Semarang, FH-UNDIP, 1986.

Adrian Sutedi, Peralihan Hak Atas Tanah dan Pendaftarannya, Cetakan.6. Jakarta: Sinar Grafika, 2014.

Boedi Harsono, UUPA, Sejarah Penyusunan, Isi, Pelaksanaan Hukum Agraria, Bagian I dan II Jilid I, Djambatan, Jakarta, 1972.

B.F. Sihombing, Evolusi Kebijakan Pertanahan Dalam Hukum Tanah Indonesia, PT Gunung Agung Tbk, Jakarta, 2005.

Edi Setiadi dan Dian Andrisari, Perkembangan Hukum Pidana di Indonesia, Edisi Pertama, Cetakan Pertama, Yogyakarta: Graha Ilmu, 2013.

Effendi Peranginangin, Hukum Agraria Indonesia Suatu Telaah dari Sudut Pandang Praktisi Hukum, CV Rajawali, Jakarta, 1986.

Gunawan Widjaya dan Kartini Mulyadi, Jual Beli, Jakarta: Raja Grafindo Persada, 2003.

Habib Adjie, Sanksi Perdata dan Administratif Terhadap Notaris Sebagai Pejabat Publik, Cet. ke-2, Refika Aditama, Bandung, 2009.

Jimly Asshiddiqie dan M Ali Syafaat, Pengantar Hukum Tata Negara, Jakarta: Konstitusi Press, 2006.

Khaerandy, Ridwan, Aspek-aspek Hukum Franchise dan Keberadaannya dalam hukum Indonesia. Yogyakarta: Majalah Unisa, UII, 1992.

Mulyoto, Legal Standing, Cakrawala Media, Yogyakarta, 2016.

Mustofa, Tuntunan Pembuatan Akta-Akta PPAT, Cetakan 3, Karya Media, Yogyakarta, 2014.

Ridwan HR, Hukum Administrasi Negara, Edisi Revisi, Cetakan Kesebelas, Jakarta: Raja Grafindo Persada, 2014.

Salim HS, Teknik Pembuatan Akta, Cetakan 2, Rajagrafindo Persada, Jakarta, 2015.

Salim H, dan Nurbani, Erlies Septiana, Penerapan Teori Hukum pada Penelitian Tesis dan Disertasi, Edisi Pertama, Cetakan Kedua, Jakarta: Rajawali Pers, 2013.

Soegondo Notodisoerjo, Hukum Notariat di Indonesia Suatu Penjelasan, Raja Grafindo Persada, Jakarta, 1993.

Subekti, R., Aneka Perjanjian, Cetakan ke-8, Citra Aditya Bakti, Bandung, 1989.

Subekti dan Tjitrosudibio, Kitab Undang-Undang Hukum Perdata, Pradnya Paramita, Jakarta, 2003.

Sri Sudaryatmi, Sukirno., TH. Sri Kartini, Beberapa Aspek Hukum Adat, Badan Penerbit Undip, Semarang, 2000.

Urip Santoso, Pejabat Pembuat Akta Tanah, Cetakan I, Kharisma Putra Utama, Jakarta, 2016. 
, Pendaftaran dan Peralihan Hak atas Tanah, Jakarta: Kencana Prenada Media Grup, 2010.

\section{Karya Ilmiah}

Retno Dewi Estiwulan., 2009, Peranan PPAT Dalam Pelaksanaan Pensertipikatan Tanah Hak Milik Di Kabupaten Jepara, Tesis, Program Studi Magister Kenotariatan Program Pascasarjana Universitas Diponegoro Semarang

Pande Putu Doron Swardika., 2014, Tanggung Jawab Dan Perlindungan Hukum Pejabat Pembuat Akta Tanah Dalam Pembuatan Akta Jual Beli Tanah, Tesis, Program Studi Kenotariatan Program Pascasarjana Universitas Udayana Bali.

Lusiana, Peranan Notaris dan Pejabat Pembuat Akta Tanah dalam memberikan perlindungan hukum kepada para Pihak dalam peralihan hak atas tanah melalui jual beli, Tesis, Magister Kenotariatan Program Pasca Sarjana Universitas Gadjah Mada Yogyakarta, 2013.

Iga Gangga Santi Dewi., Peran Camat Selaku Pejabat Pembuat Akta Tanah (PPAT) dalam Jual Beli Tanah, pandecta, Volume 5. Nomor 2. Juli 2010 Pandecta http://journal.unnes.ac.id/nju/index.php/pandecta.

\section{Peraturan PerUndang-Undangan}

Undang-Undang Dasar Negara Republik Indonesia Tahun 1945.

Undang-Undang Nomor 5 Tahun 1960 tentang Peraturan Dasar Pokok-Pokok Agraria (Lembaran Negara Tahun 1960 Nomor 104, Tambahan Lembaran Negara Nomor 2043).

Undang-Undang Nomor 2 Tahun 2014 tentang Perubahan Atas Undang-Undang Nomor 30 Tahun 2004 tentang Jabatan Notaris (Lembaran Negara Tahun 2014 Nomor 3, Tambahan Lembaran Negara Nomor 5491).

Undang-Undang Nomor 73 Tahun 1958 tentang berlakunya Undang-Undang No.

1 Tahun 1946 tentang Peraturan Hukum Pidana untuk Seluruh Wilayah Republik Indonesia dan Mengubah Kitab Undang-Undang Hukum Pidana (Lembaran Negara Tahun 1958 Nomor 127, Tambahan Lembaran Negara Nomor 1660).

Undang-Undang Nomor 8 Tahun 1981 tentang Hukum Acara Pidana (Lembaran Negara Tahun 1981 Nomor 76, Tambahan Lembaran Negara Nomor 3209).

Undang-Undang Nomor 51 Tahun 2009 Tentang Perubahan Kedua Atas UndangUndang Nomor 5 Tahun 1986 Tentang Peradilan Tata Usaha Negara (Lembaran Negara Tahun 2009 Nomor 160, Tambahan Lembaran Negara Nomor 5079).

Peraturan Pemerintah Nomor 37 Tahun 1998 tentang Peraturan Jabatan Pejabat Pembuat Akta Tanah (Lembaran Negara Tahun 1998 Nomor 52, Tambahan Lembaran Negara Nomor 3746). 
Peraturan Pemerintah Nomor 24 Tahun 1997 tentang Pendaftaran Tanah (Lembaran Negara Tahun 1997 Nomor 59, Tambahan Lembaran Negara Nomor 3696).

Peraturan Kepala BPN Nomor 8 Tahun 2012 tentang Perubahan Atas Peraturan Menteri Negara Agraria/Kepala BPN Nomor 3 Tahun 1997 tentang Ketentuan Pelaksanaan Peraturan Pemerintah Nomor 24 Tahun 1997 tentang Pendaftaran Tanah.

Peraturan Kepala BPN Nomor 23 Tahun 2009 tentang Perubahan Atas Peraturan Kepala BPN Nomor 1 Tahun 2006 tentang Ketentuan Pelaksanaan Peraturan Pemerintah Nomor 37 Tahun 1998 tentang Peraturan Jabatan Pejabat Pembuat Akta.

Peraturan Kepala BPN Nomor 1 Tahun 2006 tentang Ketentuan Pelaksanaan Peraturan Pemerintah Nomor 37 Tahun 1998 tentang Peraturan Jabatan Pejabat Pembuat Akta.

Peraturan Menteri Agraria/Kepala BPN Nomor 3 Tahun 1997 tentang Ketentuan Pelaksanaan Peraturan Pemerintah Nomor 24 Tahun 1997 tentang Pendaftaran Tanah.

UU No. 20 Th 2000 yang menggantikan UU No. 21 Th 1997 tentang Bea Perolehan Hak Atas Tanah dan Bangunan (BPHTB)

\section{Putusan Pengadilan}

Putusan Perdata Pengadilan Negeri Sleman pada Tingkat Pertama dalam Perkara Nomor No. 83/Pdt.G/2013/PN.Slmn. 